\title{
EVIDENCE FOR A DIRECT EFFECT OF SERUM SODIUM CONCENTRATION ON SODIUM REABSORPTION *
}

\author{
By CARL GOLDSMITH, $\dagger$ FLOYD C. RECTOR, JR. AND DONALD W. SELDIN
}

(From the Department of Internal Medicine, The University of Texas Southwestern Medical School, Dallas, Texas)

(Submitted for publication July 31, 1961 ; accepted November 20, 1961)

The mechanisms that modulate the renal excretion of sodium have not been completely defined. Impressive evidence has been assembled establishing the individual contributions of alterations in glomerular filtration rate (GFR), adrenal cortical activity, and some function of effective extracellular fluid (ECF) volume (1-4). A fourth factor influencing sodium excretion is the restraining action of unreabsorbed non-ionic solutes, such as mannitol, and of unreabsorbed anions, such as sulfate. Finally, it has been suggested that the concentration of serum sodium might also influence sodium excretion.

The role of the concentration of serum sodium per se in the regulation of sodium reabsorption, however, is not nearly so well defined. This uncertainty stems largely from the fact that manipulations designed to alter the concentration of serum sodium usually change the filtered load of soduim, ECF volume, and perhaps adrenocortical activity, in such a manner that the contribution of serum sodium is obscured. In the case of hypernatremia, Baldwin, Kahana and Clarke (5) showed that the natriuresis induced by the administration of hypertonic saline correlated more closely with the elevated serum sodium concentration than with the increased filtered load of sodium and attributed this to a direct suppression of renal tubular sodium reabsorption. Selkurt and Post (6), however, found that during the infusion of hypertonic saline into one renal artery of the dog, tubular sodium reabsorption remained constant or increased, and that the natriuresis on

* This study was supported in part by a grant from The National Institutes of Health and in part by a grant from the Dallas Heart Association.

$\dagger$ Work done during tenure of a Clinical Traineeship of The National Institutes of Health. Present address: Department of Internal Medicine, Medical College of Virginia, Richmond, Va. the perfused side resulted solely from increased filtered sodium.

The effect of hyponatremia is equally uncertain. Sims, Welt, Orloff and Needham (7) found an impaired ability to excrete acute sodium loads in patients with hyponatremia associated with pulmonary tuberculosis. On the other hand, other investigators have found that patients and dogs with dilutional hyponatremia have an enhanced ability to excrete sodium loads (8-11). In the latter studies, however, the effect of hyponatremia is obscured by an increase in GFR and a suppression of aldosterone secretion, both secondary to an expansion of ECF volume. It is not clear, therefore, that either hyponatremia or hypernatremia per se has any influence on sodium excretion.

To determine whether the concentration of serum sodium does have any direct effect on the tubular reabsorption of sodium, sodium excretion during mannitol diuresis was compared in normal and hyponatremic dogs. Similar studies were also conducted in one patient with cerebral hyponatremia.

\section{METHODS}

Female mongrel dogs, weighing 8 to $18 \mathrm{~kg}$, were tubefed once daily an artificial diet which provided $4.3 \mathrm{mEq}$ potassium, $1.5 \mathrm{mEq}$ sodium, $1.0 \mathrm{~g}$ protein, 27 calories, and $30 \mathrm{ml}$ water per $\mathrm{kg}$ body weight per day. Dogs on sodium restriction received an identical diet except that the sodium content provided less than $0.02 \mathrm{mEq}$ per $\mathrm{kg}$ body weight per day. The amount of diet fed any given dog was kept constant.

Acute experiments were performed to evaluate sodium and potassium excretion and $\mathrm{T}^{\mathrm{c}} \mathrm{H}_{2} \mathrm{O}$ formation during mannitol diuresis. Food and water were withheld for 16 to 24 hours preceding the experiment. Two hours prior to study, $5 \mathrm{U}$ vasopressin (Pitressin Tannate in oil) was administered intramuscularly. Dogs were lightly anesthetized with sodium pentobarbital. A solution containing 10 per cent mannitol, 5 per cent dextrose, and 75 mmoles $\mathrm{NaCl}$ per $\mathrm{L}$ (to replenish sodium loss produced 
by mannitol diuresis) (12) was infused at $1 \mathrm{ml}$ per minute during the 30 -minute equilibration period and subsequently increased in stepwise fashion to produce graded solute diuresis. To assure sustained maximum levels of antidiuretic hormone $(\mathrm{ADH})$, vasopressin, 33 $\mathrm{mU}$ per $\mathrm{kg}$ body weight, was given with the priming dose of inulin and thereafter continuously infused at the rate of $50 \mathrm{mU}$ per hour in 5 per cent dextrose in water adjusted to $\mathrm{pH} 5.5$ with acetic acid. Inulin was infused constantly at a rate of $10 \mathrm{mg}$ per minute throughout the study. Methods for collecting and analyzing blood and urine have been described previously (13).

At least 3 days elapsed between consecutive studies on any given dog. In sodium-deprived dogs obligatory sodium loss during mannitol diuresis, in excess of the sodium administered in the infusion, averaged $20 \mathrm{mEq}$; therefore, this amount of additional sodium was given with the next feeding after study. Free access to water was allowed all dogs until 48 hours prior to study to prevent dehydration, and iron was given intramuscularly to prevent iron deficiency.

The effects of variations in serum sodium concentration, aldosterone activity, and GFR on sodium and potassium excretion and $\mathrm{T}^{\mathrm{c}} \mathrm{H}_{2} \mathrm{O}$ formation during mannitol diu- resis were investigated in dogs treated in the following ways.

A. Sodium-fed control. Twelve dogs received sodiumcontaining diet for $\mathbf{2}$ to $\mathbf{5}$ days.

$B$. Sodium deprivation. Eight dogs were fed sodiumfree diet for 4 to 7 days.

C. Aldosterone. Nine sodium-fed dogs were given $d, l$-aldosterone, ${ }^{1} 200$ to $500 \mu \mathrm{g}$ per $\mathrm{kg}$ body weight intravenously, 2 hours prior to onset of the study.

$D$. Chronic hyponatremia. Twelve studies were done on ten dogs receiving either the sodium-containing or the sodium-free diet as indicated. In addition, each dog received $5 \mathrm{U}$ vasopressin tannate in oil intramuscularly at 7:00 a.m. and 4:00 p.m. daily. Additional water was given by tube in an amount equal to 1 to 3 per cent of the body weight per day.

$E$. Raising GFR during hyponatremia. Two hyponatremic dogs were given $40 \mathrm{mg}$ methylprednisolone intramuscularly twice daily for 3 days prior to study.

F. Acute hyponatremia. Three sodium-fed dogs were given sufficient water by stomach tube to lower serum

${ }^{1}$ Kindly supplied by Dr. Robert Gaunt, Ciba Inc., Summit, N. J.

TABLE I

Effect of variations in dietary sodium, serum sodium concentration, and $G F R$ on electrolyte excretion during mannitol diuresis in the dog *

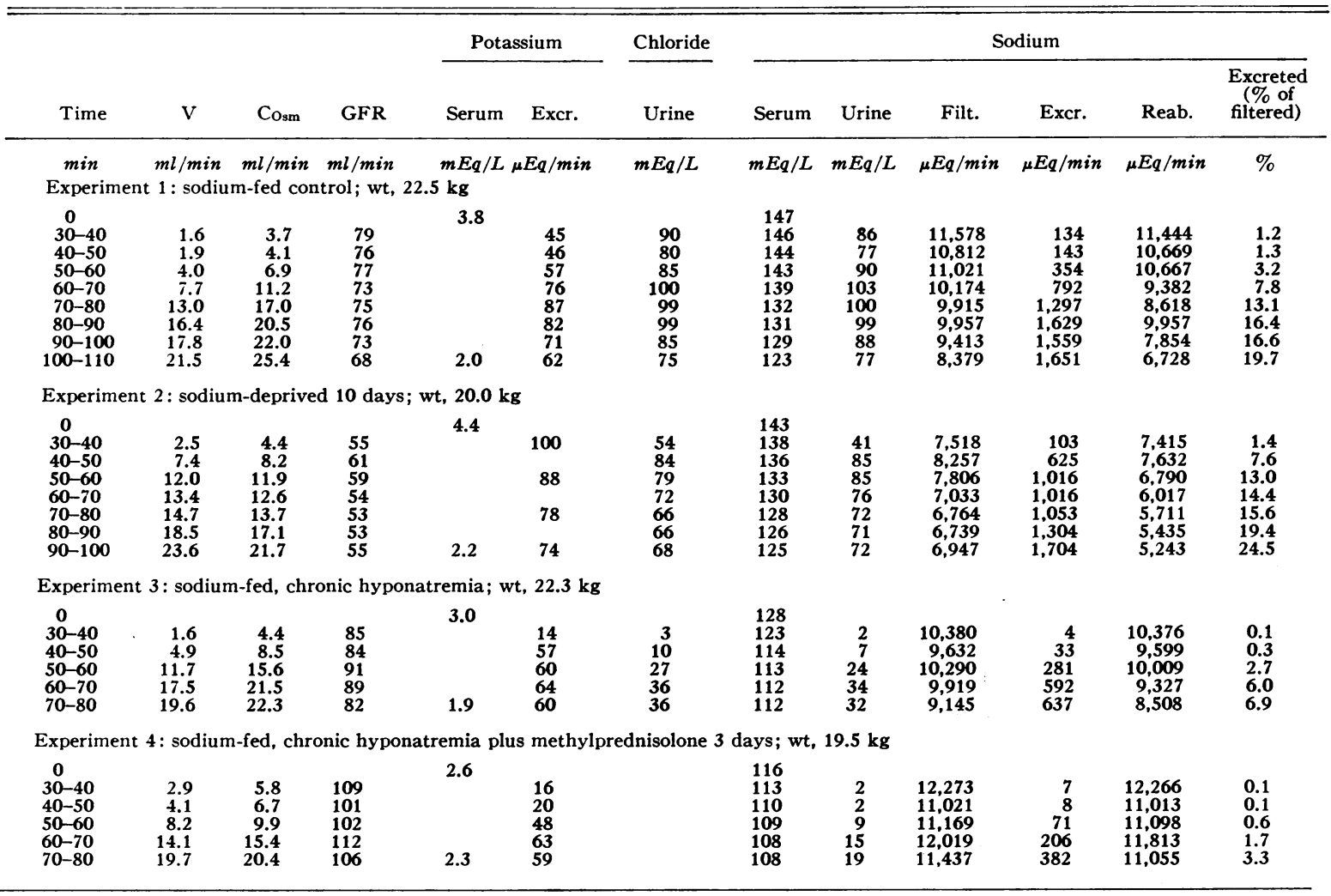

* All 4 experiments were performed on Dog 39 anesthetized with sodium pentothal. An infusion of $10 \%$ mannitol and $5 \%$ dextrose in $75 \mathrm{mM}$ saline was begun at zero time in each experiment. 


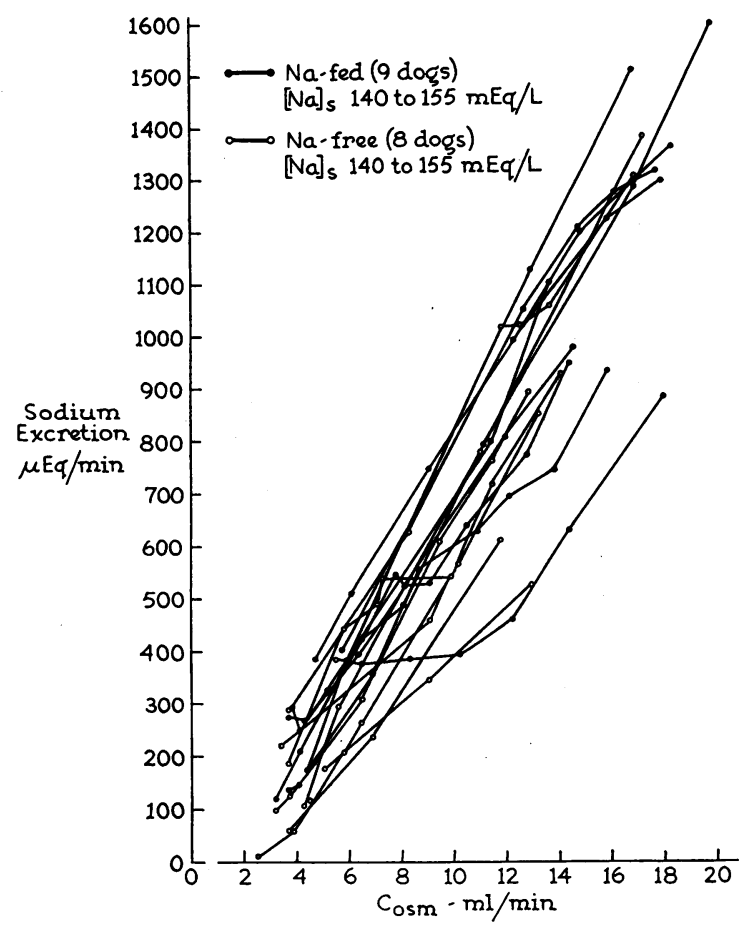

Fig. 1. Relation OF SODIUM EXCRETION TO OSMOLAR CLEARANCE IN DOGS DURING MANNITOL DIURESIS.

sodium approximately $25 \mathrm{mEq}$ per $\mathrm{L}$ on the morning of the study after the usual injection of vasopressin tannate in oil. The experiment was started 90 to 120 minutes after administration of the water.

G. Patient study. A 57 year old woman with undiagnosed cerebral disease developed dilutional hyponatremia secondary to the inappropriate secretion of $A D H$. While she was on a regular hospital diet with free access to salt and water, her serum sodium fell to $121 \mathrm{mEq}$ per $\mathrm{L}$. A study was done at this time. The hyponatremia was then corrected by restricting water to $500 \mathrm{ml}$ per day. The study was repeated when the serum sodium was 144 $\mathrm{mEq}$ per $\mathrm{L}$. The method of study was identical to that used in the dogs.

\section{RESULTS}

In all studies, sodium excretion is plotted as a function of osmolar clearance rather than of urine flow, since during mannitol diuresis it is the increase in osmolar excretion rather than in the final urine volume that is responsible for augmented sodium excretion.

GFR remained stable throughout most studies and, since acute changes in filtration rate markedly alter sodium excretion, only those studies in which GFR was relatively stable are reported in this paper.
Dogs with normal serum sodium. Mannitol diuresis in sodium-fed animals impairs the reabsorption of sodium, causing an increased excretion in approximately linear relation to $\mathrm{C}_{\mathrm{Osm}}$ (Table I, experiment 1; Figure 1, closed circles). A similar relationship obtains whether sodium excretion is expressed in absolute amounts (microequivalents per minute) or as the per cent of filtered sodium excreted (Table I). The natriuretic effect of mannitol is not significantly altered by sodium restriction (Table I, experiment 2; Figure 1, open circles). This suggests that increased aldosterone secretion secondary to prolonged salt deprivation does not enhance sodium reabsorption during mannitol diuresis. This interpretation is further substantiated by the experiment typified in Figure 2 in which massive doses of aldosterone failed to prevent the normal acceleration of sodium excretion during mannitol diuresis.

Potassium excretion increases slightly or remains relatively constant during the course of a mannitol diuresis in both sodium-fed and sodiumdeprived dogs. In these and all subsequent studies, chloride excretion paralleled that of sodium.

Hyponatremic dogs. Dogs which had previously been studied while on sodium-feeding alone were rendered hyponatremic for at least 3 days by the administration of vasopressin and excess



Fig. 2. Failure of aldosterone administration to PREVENT THE RISE IN SODIUM EXCRETION PRODUCED BY MANNITOL DIURESIS. 
water. The protocol of such an experiment is presented in Table I, experiment 3. Hyponatremia results in a marked diminution in sodium excretion regardless of whether the animal is sodium-fed or sodium-deprived (Figure 3 ). The greater scatter in these studies reflects, in part, individual variations in the response to mannitol diuresis. A series of studies on a single dog, which obviates this variation, shows the marked effect of chronic hyponatremia on sodium excretion irrespective of dietary sodium (Figure 4). An additional factor causing the scatter of the data in Figure 3 is a variation in the degree of hyponatremia. This is illustrated by examining the relationship between sodium excretion at a

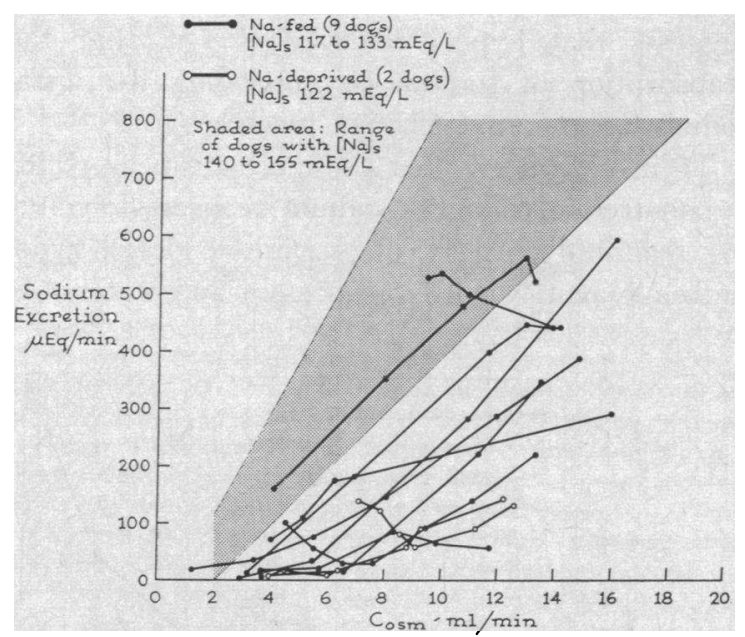

Fig. 3. EFFECT OF HYPONATREMIA ON SODIUM EXCRETION DURING MANNITOL DIURESIS IN SODIUM-FED AND SODIUM-DEPRIVED DOGS. Hyponatremia uniformly depresses the excretion of sodium.

given $\mathrm{C}_{\mathrm{Osm}}$ (arbitrarily chosen as $12 \mathrm{ml}$ per minute) and the initial serum sodium (Figure 5). The roughly linear relationship obtained shows that the diminished natriuretic effect of mannitol is proportional to the severity of the hyponatremia and independent of the sodium intake.

The diminished sodium excretion during hyponatremia cannot be attributed to reduction in the filtration of sodium. This became apparent when filtered sodium was examined by comparing the filtration, reabsorption, and excretion of sodium at identical osmolar clearances ${ }^{2}$ in individual

2 In some dogs it was necessary to interpolate between collection periods to obtain values at identical osmolar clearances.

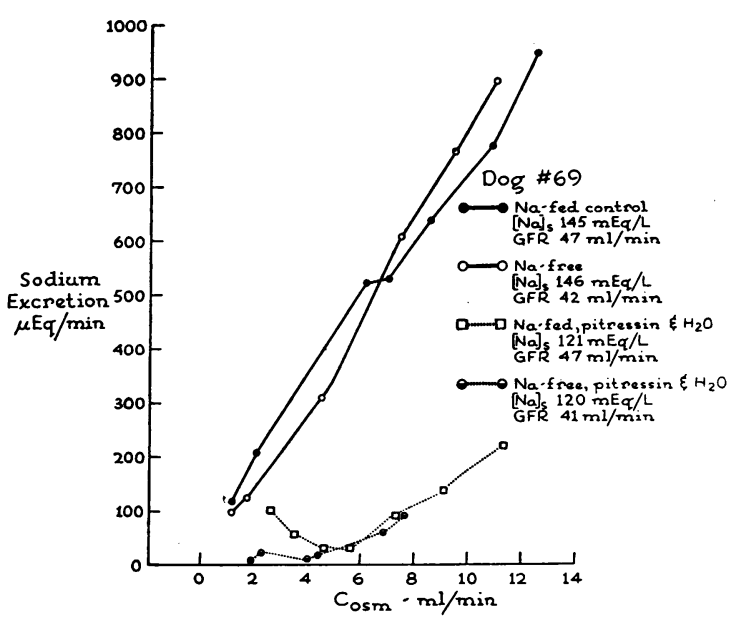

Fig. 4. Comparison IN A SINGLE DOG OF THE EFFECTS OF VARIATIONS IN DIETARY SODIUM AND SERUM SODIUM CONCENTRATION ON SODIUM EXCRETION DURING MANNITOL DIURESIS. When the serum sodium is comparably depressed, hyponatremia reduces sodium excretion to the same extent irrespective of the sodium intake.

sodium-fed dogs when the initial serum sodium concentration was normal and low (Table II). As a consequence of marked rises in GFR, filtered sodium actually increased in four hyponatremic dogs, $74 \mathrm{~A}, 74 \mathrm{~B}, 83,68$, but sodium reabsorption increased to a greater extent, resulting in de-

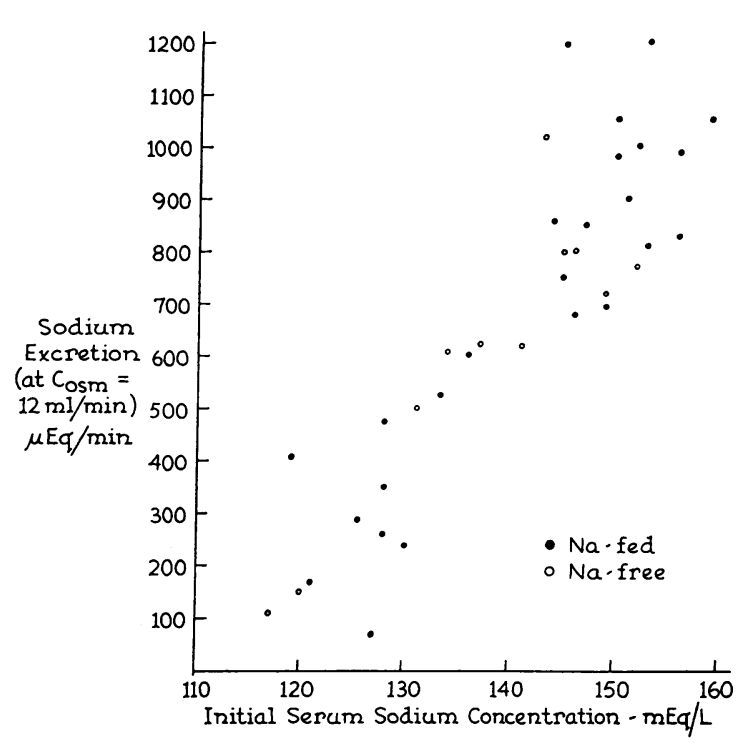

Fig. 5. RELAtionship OF SODIUM EXCRETION TO SERUM SODIUM CONCENTRATION DURING MANNITOL DIURESIS. In order to compare the influence of hyponatremia at comparable levels of mannitol diuresis, sodium excretion was arbitrarily chosen at a $\mathrm{C}_{\mathrm{sm}}$ of $12 \mathrm{ml}$ per minute. 


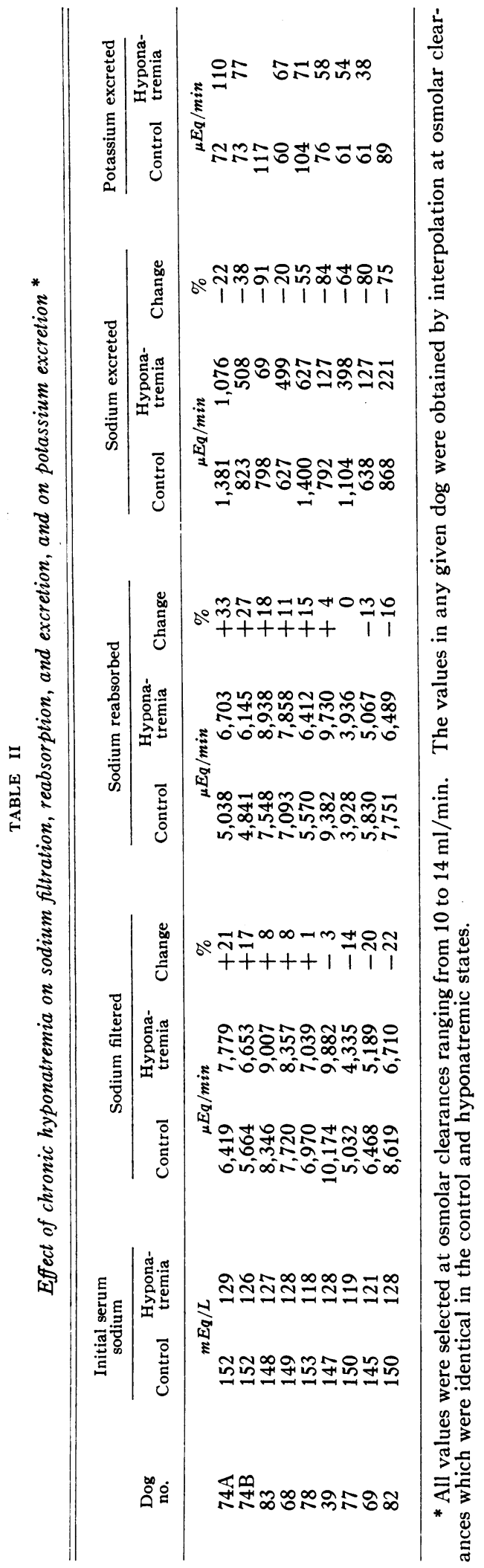

creased excretion. In Dogs 78 and 39, the filtered load of sodium did not change significantly, yet reabsorption increased and excretion fell. In addition, GFR was further increased in two hyponatremic dogs with methylprednisolone (Table I, experiment 4). Sodium excretion and reabsorption increased to a comparable extent, thereby preventing any rise in sodium excretion above that noted in hyponatremia alone (Table I, experiment 3 ). These results clearly indicate that hyponatremia reduces the excretion of sodium, not by reducing the filtered sodium, but rather by increasing tubular reabsorption.

Despite large increases in sodium reabsorption, potassium excretion was the same or slightly lower in hyponatremic dogs (Table II). This suggests that hyponatremia does not alter the reabsorption of sodium by enhancing the distal sodium-potassium exchange mechanism.

To investigate further the mechanism by which hyponatremia enhances sodium reabsorption during mannitol diuresis, dogs were rendered hyponatremic acutely with vasopressin and water. In

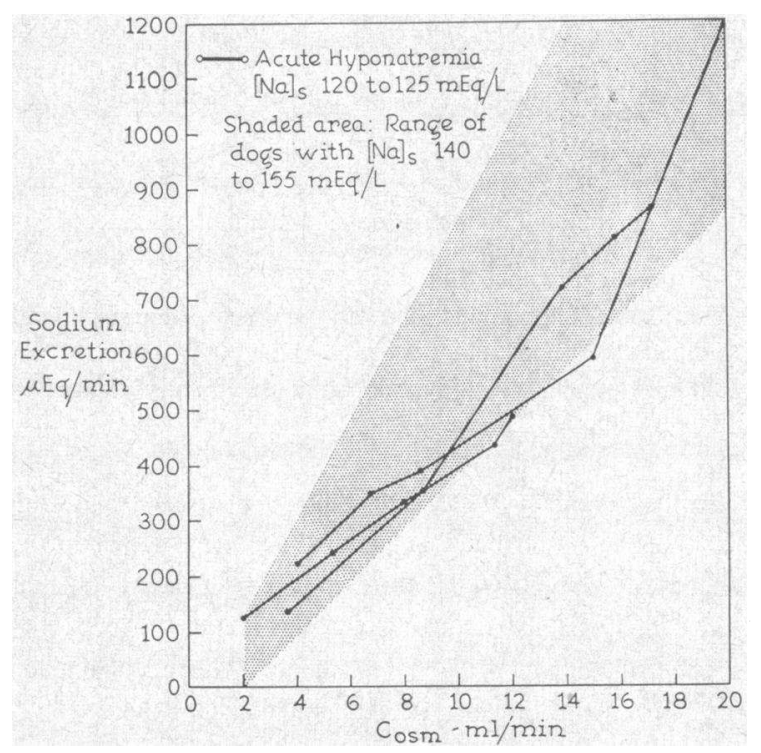

Fig. 6. EfFects of acute hyponatremia on the naTRIURETIC EFFECT OF MANNITOL DIURESIS. All three dogs were studied within 2 hours of the administration of vasopressin and water. Serum sodiums were 121, 122, and $133 \mathrm{mEq}$ per $\mathrm{L}$ after the water load and prior to the mannitol infusion. All three dogs displayed the usual depression of sodium excretion when subsequently studied during chronic hyponatremia with comparable levels of initial serum sodium. 
TABLE III

Effect of hyponatremia on sodium and potassium excretion during mannitol diuresis in a patient with cerebral hyponatremia

\begin{tabular}{|c|c|c|c|c|c|c|c|c|c|c|}
\hline \multirow[b]{3}{*}{ Time } & \multirow[b]{3}{*}{$\mathrm{V}$} & \multirow[b]{3}{*}{ GFR } & \multirow{2}{*}{\multicolumn{2}{|c|}{ Potassium }} & \multirow[b]{3}{*}{ Serum } & \multicolumn{4}{|c|}{ Sodium } & \multirow{3}{*}{$\begin{array}{l}\text { Excreted } \\
\text { ( } \% \text { of } \\
\text { filtered) }\end{array}$} \\
\hline & & & & & & & & & & \\
\hline & & & Serum & Excr. & & Urine & Filt. & Excr. & Reab. & \\
\hline $\min$ & \multicolumn{2}{|c|}{$m l / m i n$} & $m E q / L$ & $\mu E q / \min$ & \multicolumn{2}{|c|}{$m E q / L$} & $\mu E q / \min$ & $\mu E q / \min$ & $\mu E q / \min$ & $\%$ \\
\hline \multicolumn{11}{|c|}{ Patient N.J., experiment 1 : hyponatremia; wt $57.3 \mathrm{~kg}$} \\
\hline 0 & & & 4.4 & & 121 & & & & & \\
\hline \multicolumn{11}{|c|}{ Infuse $10 \%$ mannitol and $5 \%$ dextrose in $75 \mathrm{mM}$ saline } \\
\hline $\begin{array}{l}30-60 \\
60-80 \\
80-90\end{array}$ & $\begin{array}{l}2.6 \\
3.6 \\
7.6\end{array}$ & $\begin{array}{l}64 \\
76 \\
73\end{array}$ & 4.0 & $\begin{array}{l}27 \\
27 \\
34\end{array}$ & $\begin{array}{l}118 \\
115 \\
113\end{array}$ & $\begin{array}{l}43 \\
41 \\
34\end{array}$ & $\begin{array}{l}7,544 \\
8,801 \\
8,312\end{array}$ & $\begin{array}{l}109 \\
146 \\
258\end{array}$ & $\begin{array}{l}7,413 \\
8,676 \\
8,054\end{array}$ & $\begin{array}{l}1.4 \\
1.7 \\
3.1\end{array}$ \\
\hline \multicolumn{11}{|c|}{ Patient N.J., experiment $2:$ after correction of hyponatremia ; wt $55.9 \mathrm{~kg}$} \\
\hline 0 & & & 4.2 & & 144 & & & & & \\
\hline \multicolumn{11}{|c|}{ Infuse $10 \%$ mannitol and $5 \%$ dextrose in $75 \mathrm{mM}$ saline } \\
\hline $\begin{array}{l}30-55 \\
55-65 \\
65-75\end{array}$ & $\begin{array}{r}4.0 \\
7.4 \\
10.8\end{array}$ & $\begin{array}{l}66 \\
63 \\
63\end{array}$ & 3.8 & $\begin{array}{l}118 \\
119 \\
131\end{array}$ & $\begin{array}{l}130 \\
127 \\
124\end{array}$ & $\begin{array}{l}96 \\
84 \\
76\end{array}$ & $\begin{array}{l}8,619 \\
8,013 \\
7,775\end{array}$ & $\begin{array}{l}380 \\
618 \\
820\end{array}$ & $\begin{array}{l}8,239 \\
7,395 \\
5,965\end{array}$ & $\begin{array}{r}4.4 \\
7.7 \\
10.5\end{array}$ \\
\hline
\end{tabular}

Figure 6 the results of three experiments are plotted. In each dog chronic hyponatremia produced the usual effect. Acute hyponatremia, on the other hand, caused no decrease in sodium excretion despite comparable reduction in serum sodium. One possible explanation for this difference is that the former group received vasopressin chronically. This possibility was excluded, however, by experiments in four dogs given vasopressin chronically in which a normal serum sodium was maintained by water restriction. These dogs displayed a response to mannitol diuresis identical to that in the control dogs. Thus, these results indicate that the increased reabsorption of sodium during mannitol diuresis in hyponatremic dogs is dependent on a chronic reduction in serum sodium.

Patient study. To determine whether hyponatremia alters the natriuretic effect of mannitol diuresis in the human as it does in the dog, two studies were done on a patient with dilutional hyponatremia secondary to inappropriate secretion of antidiuretic hormone. The initial study, done when the patient was hyponatremic, shows a markedly lower sodium excretion during mannitol diuresis as compared with the results 4 weeks later after the serum sodium had been corrected to normal by means of water restriction (Table III). Again this decreased excretion of sodium represents increased tubular reabsorption rather than decreased filtration.

The excretion of potassium was much lower during hyponatremia. This suggests that the distal tubular sodium-potassium exchange mechanism is not involved in the enhanced reabsorption of sodium, and moreover, that less sodium was actually being delivered to the distal tubule.

\section{DISCUSSION}

Under normal circumstances, mannitol diuresis results in an acceleration of sodium excretion which is linearly related to osmolar clearance. This relationship is unaltered by either the administration of aldosterone or sodium deprivation, but is changed by chronic hyponatremia in such a fashion that sodium excretion is much lower at any given rate of urine flow. This effect is not the result of a lowered filtered sodium since a comparable reduction in filtered sodium via a decreased GFR during sodium deprivation, when the concentration of serum sodium is normal, does not reduce the natriuresis from mannitol diuresis. In some of the hyponatremic dogs, GFR actually rose so that filtered sodium increased, yet sodium excretion was low (Table II). Furthermore, diminution of filtered sodium by acute hyponatremia does not depress sodium excretion dur- 
ing mannitol diuresis. Thus, the effect of chronic hyponatremia on sodium excretion during mannitol diuresis is independent of changes in the filtered load of sodium and represents an actual increase in tubular reabsorption.

The mechanism by which mannitol diuresis promotes sodium excretion in normal dogs was considered by Wesson and Anslow (14) who postulated that a non-reabsorbable solute such as mannitol, by inhibiting the back-diffusion of water in the proximal tubule, lowers the concentration of tubular sodium to a level which prevents further sodium reabsorption. Micropuncture studies have shown that during mannitol diuresis tubular fluid sodium concentration falls to a minimum value of 70 per cent that of plasma (15-17). Thus, in the normal dog, mannitol diuresis causes the delivery of increasingly greater volumes of fluid (with a minimum sodium concentration of about $80 \mathrm{mEq}$ per L) to the distal tubule. If it is assumed that the mechanisms for sodium reabsorption in the distal tubule become saturated, then proximal tubular fluid is swept unaltered into the urine ${ }^{3}$ and sodium excretion rises proportionally with increasing urine flow.

The natriuretic action of mannitol is markedly impaired by chronic hyponatremia. This effect might result from the failure of mannitol to increase the delivery of sodium out of the proximal tubule or from an increased capacity of the distal portions of the nephron to reabsorb sodium during hyponatremia. The results of the present studies suggest that the enhanced sodium reabsorption in chronic hyponatremia occurs in the proximal rather than in the distal tubule. First, aldosterone, which is regarded as a potent stimulator of distal tubular sodium reabsorption, does

\footnotetext{
3 Gottschalk (17) has demonstrated that during extreme mannitol diuresis tubular fluid is isotonic leaving the proximal tubule and hypotonic entering the distal tubule. This strongly suggests that the mechanism for sodium reabsorption in the thick ascending limb is not saturated during mannitol diuresis. The arguments subsequently advanced in the discussion to indicate that the site of enhanced sodium reabsorption during chronic hyponatremia is the proximal tubule more properly apply to the entire proximal portion of the nephron. The term proximal tubule, therefore, is used in the present discussion not in a strict anatomical sense, but rather, more loosely, to designate that portion of the nephron proximal to the distal convoluted tubule.
}

not decrease sodium excretion in normal dogs during mannitol diuresis. Second, despite increased reabsorption of sodium in hyponatremia, there is no concomitant increase in potassium excretion (Table II), indicating that the distal sodium-potassium exchange is not involved. Moreover, in the patient as well as in two hyponatremic dogs, potassium excretion was lower than in control studies (Table III), suggesting that less sodium is being delivered to the distal tubule in hyponatremia. Therefore, it would appear from this evidence, admittedly indirect, that the site of enhanced sodium reabsorption in hyponatremia is predominantly in the proximal tubule.

Accelerated sodium reabsorption in the proximal tubule during hyponatremia could occur if the factor limiting reabsorption in mannitol diuresis were not a minimum concentration of tubular sodium but rather a maximum concentration gradient between tubular and peritubular fluid. Under such circumstances, the establishment of the same concentration gradient in normal and hyponatremic states would result in a lower concentration of tubular sodium leaving the proximal tubule in the latter circumstance; consequently, during hyponatremia sodium excretion would be less at any given level of mannitol diuresis. For example, a maximum gradient of $50 \mathrm{mEq}$ per $\mathrm{L}$ with a serum sodium of $130 \mathrm{mEq}$ per $\mathrm{L}$ (the usual value in normal dogs during extreme mannitol diuresis) would give a sodium concentration of $80 \mathrm{mEq}$ per $\mathrm{L}$ in fluid issuing from the proximal tubule. This value is in agreement with direct measurements by micropuncture (15-17). When serum sodium is lowered to $110 \mathrm{mEq}$ per $\mathrm{L}$ (the usual value in hyponatremic dogs during extreme mannitol diuresis), a maximum gradient of $50 \mathrm{mEq}$ per $\mathrm{L}$ would result in a sodium concentration of $60 \mathrm{mEq}$ per $\mathrm{L}$. Thus, a fall in serum sodium of $20 \mathrm{mEq}$ per L would result in a depression of sodium excretion during high rates of mannitol diuresis by about 25 per cent. In the present studies, serum sodium in the hyponatremic dogs actually fell by an average of 23 $\mathrm{mEq}$ per L. However, the average fall in sodium excretion was 59 per cent and in some animals was as high as 91 per cent, values far in excess of those expected were a fixed maximum gradient the limiting factor in proximal tubular sodium reabsorption (Table II). This disproportionate 
fall in sodium excretion in chronic hyponatremia suggests that the enhanced sodium reabsorption is not the result of a fixed concentration gradient for sodium reabsorption operating against a lower plasma concentration but rather of an augmented ability of the proximal tubule to reabsorb sodium against greater than normal gradients.

The effect of hyponatremia on the ability of the proximal tubule to reabsorb sodium against concentration gradients can be examined by estimating the concentration of sodium in proximal tubular fluid from the concentration of sodium in the bladder urine during extreme mannitol diuresis. It is assumed that during mannitol diuresis the capacity of the distal tubule to reabsorb sodium becomes saturated; consequently, increasing mannitol diuresis beyond this point sweeps proximal tubular fluid unaltered into the final urine. Therefore, the concentration of sodium in the urine will approach a limiting value which is equivalent to the concentration in the fluid leaving the proximal tubule. The concentration of sodium in proximal tubular fluid, as estimated from the limiting concentration of sodium in the urine, is directly related to the concentration of serum sodium obtained prior to the administration of mannitol (initial serum sodium) (Figure 7). The calculated concentration of proximal tubular sodium, which was approximately $75 \mathrm{mEq}$ per L

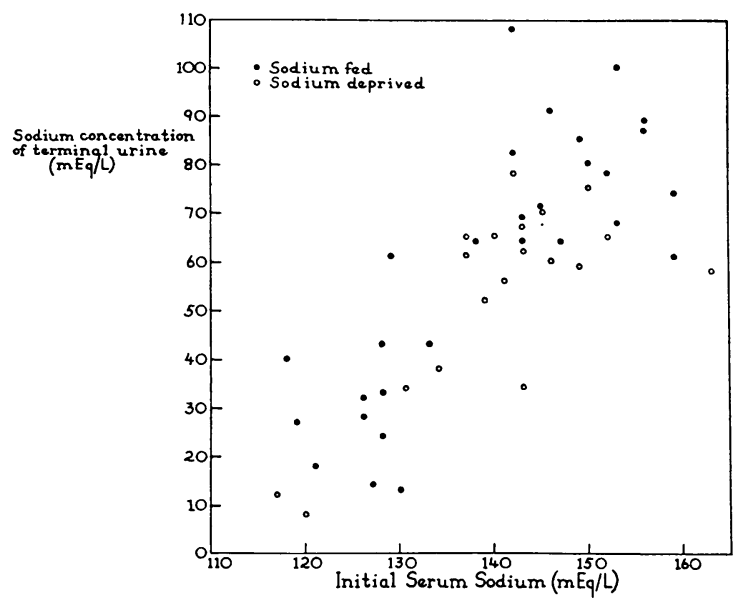

Fig. 7. Relationship of the estimated concentraTION OF SODIUM IN FLUID LEAVING THE PROXIMAL TUBULE TO THE INITIAL SERUM SODIUM CONCENTRATION. The concentration of sodium in proximal tubular fluid was estimated from the limiting concentration of sodium in the urine (see text).

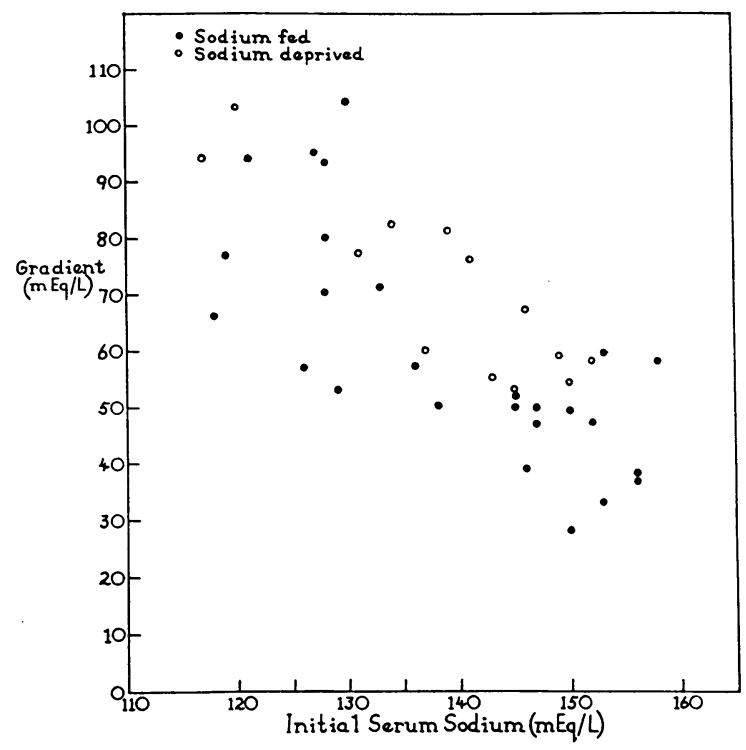

Fig. 8. Relationship of the concentration gradiENT OF SODIUM IN THE PROXIMAL TUBULE TO THE INITIAL SERUM SODIUM CONCENTRATION. The gradient is derived from the difference between the estimated sodium concentration of proximal tubular fluid at extreme mannitol diuresis ( $\mathrm{C}_{0 \mathrm{sm}}=$ approximately $20 \mathrm{ml}$ per minute) and the sodium concentration of blood obtained simultaneously.

when initial serum sodiums were 140 to $150 \mathrm{mEq}$ per $\mathrm{L}$, fell to values as low as $10 \mathrm{mEq}$ per $\mathrm{L}$ during extreme hyponatremia.

The concentration gradient of sodium across the proximal tubule can be obtained from the difference between the calculated proximal tubular sodium concentration and the simultaneous serum sodium concentration during extreme mannitol diuresis. As seen in Figure 8, the gradient increases from a value of approximately $45 \mathrm{mEq}$ per $\mathrm{L}$ at initial serum sodium concentrations of about $155 \mathrm{mEq}$ per $\mathrm{L}$ to a value of approximately $90 \mathrm{mEq}$ per $\mathrm{L}$ when the initial serum sodium falls to $120 \mathrm{mEq}$ per $\mathrm{L}$.

These results suggest that chronic hyponatremia blunts the natriuretic effect of mannitol by substantially increasing the ability of the proximal tubule to reabsorb sodium against concentration gradients. The fact that acute hyponatremia does not produce this phenomenon indicates that the proximal tubular sodium reabsorptive mechanism undergoes adaptive changes which are dependent on a chronic reduction in serum sodium.

According to current concepts (18) the proximal tubular reabsorption of sodium is accom- 
plished by a sodium pump located on the peritubular surface of the renal tubular cell. The action of this pump maintains a low intracellular sodium concentration, thus allowing tubular sodium to diffuse through the luminal membrane along its concentration gradient. Therefore, the ability of the proximal tubule to establish concentration gradients between tubular fluid and blood is dependent upon the permeability of the luminal membrane to sodium and the affinity of the pump for sodium. In addition, it appears that the peritubular membrane of the proximal tubular cell is also permeable to sodium, as evidenced by results obtained in recent stop-flow and micropuncture studies (19-21). The presence of significant passive diffusion of sodium across the proximal tubule could greatly modify the maximum concentration gradient that can be established by the active transport system. Kiil, Aukland and Refsum (22), in recent studies, found that the decrease in net sodium reabsorption during mannitol diuresis occurred without changing renal oxygen consumption. On the basis of these studies, they postulated that during mannitol diuresis net sodium reabsorption decreased, not as a consequence of diminished active transport of sodium, but rather because of increased net passive diffusion into the lumen along the concentration gradients created by mannitol. In terms of this model, there are three possible ways in which chronic hyponatremia could enhance proximal tubular sodium reabsorption: by decreasing the over-all permeability of the tubular epithelium (hence limiting passive diffusion back into the tubular lumen); by increasing the affinity of the pump for sodium; or by increasing the permeability of the luminal membrane, thereby permitting more rapid accession of sodium to the pump. The present studies provide no evidence to discriminate among these possibilities.

\section{SUM MARY}

The effects of hyponatremia on sodium and potassium excretion during mannitol diuresis were studied in dogs by varying the serum sodium concentration, sodium intake, aldosterone activity, and GFR. Mannitol diuresis causes increasing sodium excretion in linear relation to osmolar clearance in dogs with a normal serum sodium.
Sodium deprivation decreases the filtration and reabsorption of sodium proportionally so that, when sodium excretion is corrected for the fall in GFR, no effect can be attributed to sodium deprivation. The administration of aldosterone has no effect on the natriuretic action of mannitol. Chronic hyponatremia, on the other hand, markedly lowers sodium excretion during mannitol diuresis, irrespective of sodium intake. This decrease in sodium excretion was associated with an absolute increase in sodium reabsorption in five of nine dogs, and an increase relative to filtered sodium in the other four. It is therefore concluded that the reduction in sodium excretion results, not from diminished sodium filtration, but rather from enhanced sodium reabsorption. Similar results were obtained on one patient with cerebral hyponatremia. This effect of chronic hyponatremia on sodium excretion cannot be reproduced by acute hyponatremia. Evidence is advanced to support the view that chronic hyponatremia diminishes sodium excretion during mannitol diuresis by enhancing the ability of the proximal tubule to reabsorb sodium against concentration gradients.

\section{REFERENCES}

1. Smith, H. W. The Kidney: Structure and Function in Health and Disease. New York, Oxford University Press, 1951, p. 295.

2. Selkurt, E. E. Sodium excretion by the mammalian kidney. Physiol. Rev. 1954, 34, 287.

3. Strauss, M. B. Body Water in Man: The Acquisition and Maintenance of the Body Fluids. Boston, Little, Brown, 1957, p. 173.

4. Kruhфffer, P. Effects of Changes in Plasma Sodium Concentration on Sodium Excretion. The Alkali Metal Ions in Biology. Berlin, Springer-Verlag, 1960, p. 233.

5. Baldwin, D., Kahana, E. M., and Clarke, R. W. Renal excretion of sodium and potassium in the dog. Amer. J. Physiol. 1950, 162, 655.

6. Selkurt, E. E., and Post, R. S. Renal clearance of sodium in the dog: Effect of increasing sodium load on reabsorptive mechanism. Amer. J. Physiol. 1950, 162, 639.

7. Sims, E. A. H., Welt, L. G., Orloff, J., and Needham, J. W. Asymptomatic hyponatremia in pulmonary tuberculosis. J. clin. Invest. 1950, 29, 1545.

8. Leaf, A., Bartter, F. C., Santos, R. F., and Wrong, O. Evidence in man that urinary electrolyte loss induced by pitressin is a function of water retention. J. clin. Invest. 1953, 32, 868. 
9. Wrong, O. The relationship between water retention and electrolyte excretion following administration of anti-diuretic hormone. Clin. Sci. 1956, 15, 401.

10. Levinsky, N. G., Davidson, D. G., and Berliner, R. W. Changes in urine concentration during prolonged administration of vasopressin and water. Amer. J. Physiol. 1959, 196, 451.

11. Carter, N. W., Rector, F. C., Jr., and Seldin, D. W. Hyponatremia in cerebral disease resulting from the inappropriate secretion of antidiuretic hormone. New Eng1. J. Med. 1961, 264, 67.

12. Giebisch, G., and Lozano, R. The effects of adrenal steroids and potassium depletion on the elaboration of an osmotically concentrated urine. J. clin. Invest. 1959, 38, 843.

13. Goldsmith, C., Beasley, H. K., Whalley, P. J., Rector, F. C., Jr., and Seldin, D. W. The effect of salt deprivation on the urinary concentrating mechanism in the dog. J. clin. Invest. 1961, 40, 2043.

14. Wesson, L. G., Jr., and Anslow, W. P., Jr. Excretion of sodium and water during osmotic diuresis in the dog. Amer. J. Physiol. 1948, 153, 465.

15. Windhager, E. E., Whittembury, G., Oken, D. E., Schatzmann, H. J., and Solomon, A. K. Single proximal tubules of the necturus kidney. III. De- pendence of $\mathrm{H}_{2} \mathrm{O}$ movement on $\mathrm{NaCl}$ concentration. Amer. J. Physiol. 1959, 197, 313.

16. Windhager, E. E., and Giebisch, G. Micropuncture study of renal tubular transfer of sodium chloride in the rat. Amer. J. Physiol. 1961, 200, 581.

17. Gottschalk, C. W. Micropuncture studies of tubular function in the mammalian kidney. Physiologist 1961, 4, no. $1,35$.

18. Giebisch, G. Measurements of electrical potentials and ion fluxes on single renal tubules. Circulation $1960,21,879$.

19. White, H. L., Rolf, D., and Tosteson, D. C. Water and sodium exchange in renal tubule fluid. Amer. J. Physiol. 1961, 200, 591.

20. Kiil, F., and Aukland, K. Renal tubular permeability to radioactive sodium, bromide, and iodide isotopes. Scand. J. clin. Lab. Invest. 1961. In press.

21. Windhager, E. E., and Giebisch, G. Comparison of short-circuit current and net water movement in single perfused proximal tubules of rat kidneys. Nature (Lond.) 1961, 191, 1205.

22. Kiil, F., Aukland, K., and Refsum, H. E. Renal sodium transport and oxygen consumption. Amer. J. Physiol. 1961, 201, 511. 